\title{
PENDAMPINGAN PENYUSUNAN ASESMEN PADA PEMBELAJARAN TEMATIK DI MASA PANDEMI DI SDN GIRIMOYO 02
}

\author{
Falistya Roisatul Mar'atin Nuro ${ }^{1}$, Delora Jantung Amelia ${ }^{2}$ \\ ${ }^{1,2)}$ Pendidikan Guru Sekolah Dasar, FKIP, Universitas Muhammadiyah Malang \\ email:falistya@umm.ac.id ${ }^{1}$, delorajantung@umm.ac.id ${ }^{2}$
}

\begin{abstract}
Abstrak
Pelaksanaan, program pengabdian masyarakat dengan judul pendampingan ini diawali dengan workshop. Kegiatan ini melibatkan kerjasama dengan SDN Girimoyo 02 Kecamatan Karangploso. Pendampingan penyusunan asesmen ini masuk pada era revolusi industri 4.0 oleh karena itu sistem pembelajarannya kita kuatkan dari segi teknologi. Pendampingan Penyusunan Asesmen Autentik Pada Pembelajaran Tematik di SDN Girimoyo 02 Kec. Karangploso Kab. Malang dilakukan melalui 4 tahapan. Yang pertama adalah kegiatan Workshop Penyusunan Asesmen Autentik, dalam kegiatan workshop terdapat 2 materi yang disampaikan yaitu pengertian, jenis-jenis dan langkah penyusunan asesmen autentik. Tahapan kedua adalah pendampingan penyusunan Asesmen autentik, pada tahap pendampingan dilakukan dengan daring (whatapps group) dan satu kali luring dengan tatap muka antara guru dan tim pengabdi. Tahapan ketiga yaitu implementasi asesmen autentik, tahapan implementasi dilakukan dengan jumlah siswa setengah dari jumlah keseluruhan dikarenakan pada situasi pandemi. Tahapan keempat dan terakhir adalah evalusi dan reflesi terkait penyusunan asesmen autentik. Kendala yang dialami ketika kegiatan pendampingan adalah waktu pendampingan yang terbilang singkat karena kegiatan penyusunan asesmen ini ditengah tengah kegiatan guru untuk mempersiapkan materi dan video untuk pembelajaran daring dan agenda sekolah
\end{abstract}

Kata Kunci: Pendampingan, Asesmen

\begin{abstract}
The implementation of this community service program with the title mentoring begins with a workshop. This activity involves collaboration with SDN Girimoyo 02 Karangploso District. Assistance in the preparation of this assessment is included in the era of the industrial revolution 4.0, therefore we strengthen the learning system in terms of technology. Assistance in Preparation of Authentic Assessments in Thematic Learning at SDN Girimoyo 02 Kec. Karangploso Kab. Malang is done through 4 stages. The first is the Workshop for the Preparation of Authentic Assessments, in the workshop there are 2 materials presented, namely the meaning, types and steps of preparing authentic assessments. The second stage is assistance for the preparation of authentic assessments, at the mentoring stage carried out online (whatapps group) and one time offline with face to face between the teacher and the service team. The third stage is the implementation of an authentic assessment, the implementation stage is carried out with half of the total number of students due to a pandemic situation. The fourth and final stage is evaluation and reflection related to the preparation of authentic assessments. The obstacle experienced when mentoring activities was the relatively short mentoring time because the assessment preparation activity was in the middle of teacher activities to prepare materials and videos for online learning and school agendas.
\end{abstract}

Keywords: Assistance, Assessment

\section{PENDAHULUAN}

Pembelajaran pada masa pandemi berbeda dengan pembelajaran sebelumnya, pada masa pandemi pembelajaran yang semula luring berubah secara daring. Pada pembelajaran tematik pada kurikulum 2013 (K13) terdapat empat bagian kompetensi yang wajib dikuasai oleh peserta didik. Kompetensi tersebut dijelaskan pada Kompetensi Inti (KI) yang terdiri dari KI 1 tentang sikap spriritual, KI 2 tentang sikap sosial, KI 3 tentang pengetahuan dan KI 4 tentang keterampilan. Pada penerapannya KI 1 dan KI 2 tidak diajarkan, melainkan dilakukan pengamatan langsung terhadap peserta didik selama kegiatan pembelajaran. Pada KI 3 dan KI 4 tentang penerapan konsep atau teori pada dunia nyata. Adapaun cara untuk mengetahui ketercapaian siswa sesuai dengan Kompetensi Inti dapat dilakukan dengan asesmen. 
Asesmen merupakan bagian dalam pembelajaran. Asesmen berfungsi untuk mengukur tingkat ketercapaian tujuan pembelajaran. Menurut Harsiati (2011:3) asesmen adalah pengumpulan data untuk menunjukkan perkembangan pembelajaran. Data yang dimaksud tentang data proses dan hasil selama proses pembelajaran berlangsung. Sesuai dengan data yang diperoleh dari kegiatan asesmen, guru dapat mengambil keputusan ketercapaian tujuan pembelajaran oleh siswa. Asesmen memiliki cakupan yang luas mulai dari kegiatan wajib ataupun opsional/tugas bagi siswa dalam pembelajaran dan kesesuaian bentuk tertentu dari asesmen dipengaruhi oleh pertimbangan disiplin ilmu dan jenis pembelajaran yang didata (Zacharis, 2010:61). Salah satu bentuk asesmen yang digunakan dalam Kurikulum 2013 yaitu asesmen autentik.

Dasar hukum penilaian autentik mengacu pada pada Permendikbud Nomor 66 Tahun 2013 tentang Standar Penilaian Pendidikan dan Permendikbud Nomor 104 Tahun 2014 tentang Penilaian Hasil Belajar menjelaskan bahwa standar penilaian pendidikan adalah kriteria mengenai mekanisme, prosedur dan instrumen penilaian hasil belajar peserta didik. Penilaian pendidikan sebagai proses pengumpulan dan pengolahan informasi untuk mengukur pencapaian hasil belajar peserta didik mencakup: penilaian autentik, penilaian diri, penilaian berbasis portofolio, ulangan, ulangan harian, ulangan tengah semester, ulangan akhir semester, ujian tingkat kompetensi, ujian mutu tingkat kompetensi, ujian nasional dan ujian sekolah/madrasah

Asesmen autentik adalah penilaian seluruh aspek dalam pembelajaran yang terdiri proses dan hasil. O'malley dan Pierce (1996:5) mengatakan bahwa asesmen autentik adalah bentuk penilaian yang menunjukkan pembelajaran siswa yang berupa pencapaian, motivasi dan sikap relevan dalam aktivitas kelas. Dari pendapat tersebut dapat dijabarkan bahwa asesmen autentik menilai ranah sikap, pengetahuan dan keterampilan. Kunanadar (2013:38) menjelaskan ciri-ciri asesmen autentik yaitu harus mengukur semua aspek, dilaksanakan selama dan proses pembelajaran, menggunakan berbagai sumber, tes hanya salah satu alat pengumpul data penialaian, tugas yang diberikan siswa bagian dari kehidupan. Memalui penerapan asesmen autentik nantinya peserta didik akan dapat menerapkan ilmu pengetahuan yang dimiliki dan dapat menyelesaikan permasalahan di kehidupan sehari-hari.

Hasil observasi awal yang telah dilakukan, ditemukan beberapa data dilapangan guru belum melakukan asesmen autentik dalam proses pembelajaran, terbukti dengan guru masih menggunakan asesmen tradisional dalam penilaian. Penilaian proses dan hasil terkadang tidak dilakukan oleh guru melainkan langsung pada penilaian akhir. Guru sudah memahami tentang pengertian assesmen akan tetapi terkendala dalam pengembangannya.

Asesmen autentik memiliki berbagai keunggulan bila dilaksanakan dalam pembelajaran. Muller (2016) menyatakan asesmen autentik memiliki manfaat sebagai berikut. Pertama, memungkinkan pendataan kemampuan siswa secara langsung. Kedua, melatih siswa tidak hanya sekedar menghafal materi, namun dapat memahami konteks pemanfaatannya dan mengonstruksi kemampuan mereka dalam kehidupan sehari-hari. Ketiga, dapat mengintegrasikan kegiatan belajar, mengajar, dan asesmen secara utuh dan sling terkait. Keempat, memberikan kesempatan bagi siswa untuk menunjukkan kemampuan mereka sebaik mungkin. Selain empat manfaat tersebut, hasil dari asesmen autentik dapat dimanfaatkan oleh guru sebaik mungkin untuk kebutuhan perkembangan siswa. Hasil asesmen yang akurat tentang kemampuan riil siswa dapat dimanfaatkan guru untuk menentukan langkah tepat dalam mengembangkan atau mengatasi permasalahan belajar yang dialami oleh siswa (Charoenchai, et al, 2015:2529).

Jenis asesmen autentik yang digunakan dalam Kurikulum 2013 yaitu observasi, portofolio, unjuk kerja, proyek, dan tes tertulis. Guru membuat asesmen dengan menuliskan kisi-kisi yang sesuai dengan kompetensi dan tujuan pembelajaran yang disesuaikan dengan keadaan siswa. Data yang diperoleh nantinya dapat menentukan keputusan penilaian sesuai dengan kriteria yang sudah ditetapkan. Berdasarkan peraturan Permendikbud No. 23 Tahun 2016 yang menyatakan bahwa pengaturan mengenai penilaian pendidikan perlu disesuaikan dengan perkembangan dan kebutuhan dalam penilaian hasil belajar siswa. Melihat gambaran diatas, tersirat bahwa Pendampingan penyusunan asesmen autentik pada pembelajaran tematik bersifat sangat penting.

Berdasarkan hasil analisis bahwa kualitas pendidik dalam konteks penyusunan asesmen autentik belum memadai dan belum optimal. Sedangkan di era globalisasi ini, guru sangat dituntut meningkatkan profesionalitasnya sebagai pengajar dan pendidik. Sebagai generasi penerus bangsa pun, peserta didik harus mampu berpola pikir kritis, inovatif, berkarakter untuk peduli dan bertanggungjawab terhadap dirinya sendiri, masyarakat dan alam sekitarnya. Oleh karena itu, sebagai 
sikap proaktif dari gambaran di atas, dosen PGSD Universitas Muhammadiyah Malang memandang perlu diadakan Pendampingan Penyusunan asesmen autentik pada pembelajaran tematik terhadap guru- guru SDN Girimoyo 02 Kecamatan Karangploso. Hasil wawancara awal yang dilakukan peneliti di SDN Girimoyo 02 kepada guru kelas rendah dan kelas tinggi, terkait tentang jenis tes yang biasa digunakan guru sering menggunakan jenis tes tertulis, dimana tes tertulis lebih fokus pada ranah pengetahuan. Dari hasil wawancara mengenai pembuatan instrumen autentik dan pembuatan rubrik, guru tidak membuat instrumen atau rubrik sendiri melainkan langsung menggunakan buku guru dan buku siswa K-13 revisi tahun 2017 yang berasal dari pemerintah. Instrumen yang terdapat dalam buku guru sudah mencakup ranah sikap, pengetahuan dan keterampilan. Wawancara berlanjut tentang penerapan penilaian sikap, guru kelas rendah cenderung menilai sikap secara subjektif dikarenakan kurang jelasnya deskriptor dan waktu penilaian sikap dilakukan, pada guru kelas tinggi penilaian sikap yang dilakukan adalah sikap spriritual pada saat doa awal pembelajaran, sedangkan sikap social guru tidak melakukan penilaian. Pada ranah keterampilan guru mengalami kesulitan dalam melakukan asesmen kinerja, proyek dan portofolio. Pemahaman konsep tentang asesmen autentik memang telah dikuasai guru melalui pelatihan-pelatihan dari Dinas Pendidikan. Pelaksanaan dan pengembangan instrumen merupakan kendala bagi guru.

\section{METODE}

Berdasarkan permasalahan di atas, peneliti tertarik untuk melakukan pendampingan penyusunan asesmen autentik pada pembelajaran tematik. Pendampingan penyusunan asesmen ini nantinya sesuai dengan Kompetensi Inti yang sudah dipaparkan di atas yaitu ranah sikap, pengetahuan dan keterampilan. Adapun solusi yang ditawarkan pada program pendampingan yaitu:

1. Workshop pendampingan asesmen autentik pada pembelajaran tematik di SDN Girimoyo 02 Kecamatan Karangploso

2. Pendampingan penyusunan asesmen

3. Implementasi asesmen yang sudah dibuat oleh guru-guru SDN Girimoyo 02 Kecamatan Karangploso

4. Refleksi dan tindak lanjut pendampingan penyusunan asesmen autentik.

Kegiatan ini dilaksanakan selama empat tahap dengan dua kali pertemuan baik secara daring maupun luring. Unsur yang terlibat yaitu pengabdi sebagai pemateri, guru dan kepala sekolah SDN Girimoyo 2 Kec. Karangploso. Pengabdi sebagai pemateri yang terlibat dalam Program IPTEKS Bagi Masyarakat (PIbM) dengan judul Pendampingan Penyusunan Asesmen Autentik pada Pembelajaran Tematik di SDN Girimoyo 02 Kec. Karangploso Kab. Malang yaitu:

1. Falistya Roisatul Mar'atin Nuro, M.Pd

2. Delora Jantung Amelia, M.Pd

3. Kepala Sekolah SDN Girimoyo 2 Kec. Karangploso

4. Guru SDN Girimoyo 2 Kec. Karangploso

\section{HASIL DAN PEMBAHASAN}

Pada kegiatan pendampingan dilakukan beberapa kegiatan antara lain sebagai berikut:

\section{Workshop tentang Asesmen Autentik pada Pembelajaran Tematik}

Pelaksanaan workshop Asesmen Autentik pada Pembelajaran Tematik di SDN Girimoyo 02 Kec. Karangploso kab. Malang telah dilaksanakan pada 18 September 2020. Terdapat perubahan rencana pelaksanaan pada awal direncanakan secara luring karena dalam situasi pandemi Covid-19 maka kegiatan workshop berjalan secara daring. Persiapan awal adalah membuat link google meet yang nantinya di sebarkan kepada guru-guru.

Kegiatan workshop dibagi tiga sesi, sesi pertama oleh Delora Jantung Amelia, M.Pd. memberikan paparan tentang pengertian dan jenis-jenis asesmen autentik. Hal ini dilakukan untuk menyamakan presepsi guru-guru tentang pengertian dan jenis-jenis asesmen autentik. Jenis-jenis asesmen autentik yang dijabarkan sesuai dengan kurikulum 2013 yaitu observasi, portofolio, unjuk kerja, proyek, dan tes tertulis. 


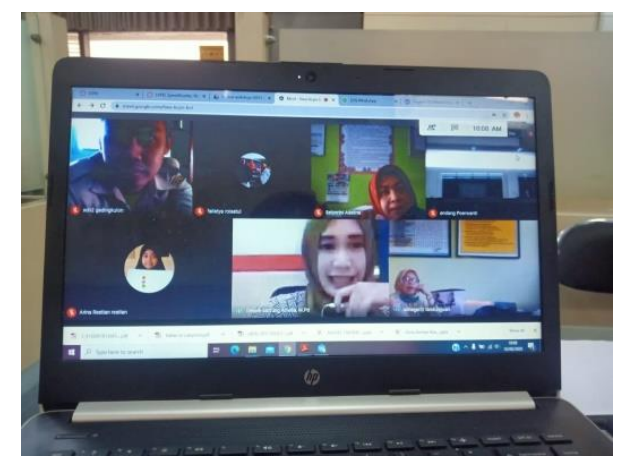

Gambar 1. Pemaparan Materi Pengertian dan jenis Asesmen oleh tim Pengabdi

Pemaparan pada sesi kedua oleh Falistya Roisatul Mar'atin Nuro, M.pd tentang Penyusunan Instrumen asesmen autentik. Hal ini disampaikan agar guru-guru mengetahui tahapan pertama sampai dengan akhir yang akan dilakukan untuk menyusun asesmen autentik. Penyampaian langkah-langkah lebih menekankan bahwa penilaian itu tidak hanya dengan tes akan tetapi bisa dilakukan melalui keterampilan siswa. Pada penilaian sikap, penentuan sikap dapat disesuaikan dengan kegiatan pembelajarannya.

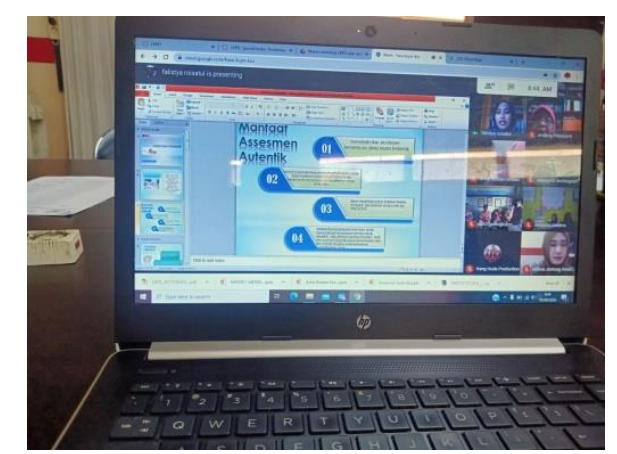

Gambar 2. Pemaparan Materi tentang Penyusunan Istrumen Autentik oleh tim Pengabdi

Setelah pemaparan dari dua tim pengabdi selesai dilanjutkan oleh sesi tanya jawab. Kegiatan workshop secara daring tidak menyurutkan semangat guru- guru untuk menambah pengalaman dan pengetahuan tentang Asesmen Autentik. Banyak sekali pertanyaan yang disampaikan oleh guru-guru terkait dengan penyusunan langkah-langkah asesmen autentik. Kegiatan Tanya jawab ini dapatmemaksimalkan hasil guru-guru dalam penyusunan intrumen asesmen.

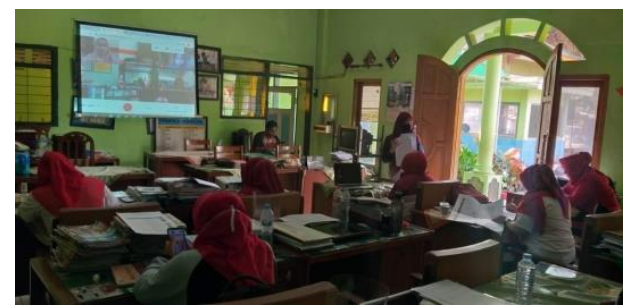

\section{Gambar 3. Antusias Guru-Guru Mengikuti Workshop Daring}

\section{Pendampingan Penyusunan Asesmen Autentik pada Pembelajaran Tematik}

Pelaksanaan pendampingan dilakukan mulai bulan Agustus 2020. Kegiatan Pendampingan dilakukan melalui online (group whatapps) dan pertemuan tatap muka. Pendampingan secara online dilakukan secara intens dan kegiatan tatap muka dilakukan satu kali. Kegiatan pendampingan diawali dengan memberikan contoh bentuk instrumen asesmen autentik melalui group whatapps, selain contoh intrumen tim pengabdi juga memberikan informasi terkait langkah-langkah dalam penyusunan intrumen. Selama proses pendampingan secara online terdapat beberapa poin intrumen asesmen yang perlu direvisi, hal ini berguna untuk memaksimalkan hasil akhir. 


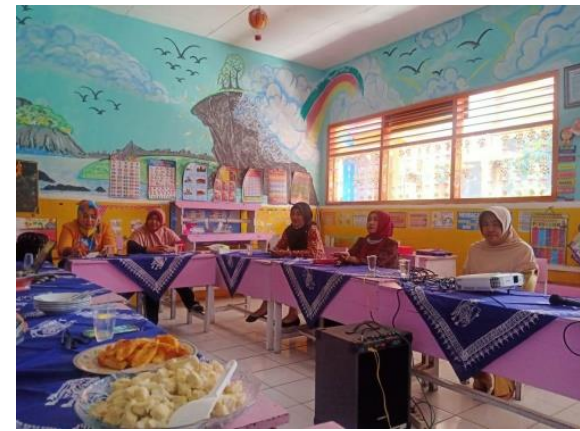

\section{Gambar 4. Kegiatan Pendampingan secara Tatap Muka}

Kegiatan pendampingan berakhir dengan kegiatan tatap muka. Kegiatan tatap muka dilaksanakan pada 15 September 2020. Pada kegiatan tatap muka masing-masing guru diminta untuk menyampaikan hasil intruemen autentik kepada tim pengabdi. Dari hasil pendampingan terakhir terdapat sedikit poin yang masih perlu dibenahi.

\section{Implementasi Asesmen Autentik pada Pembelajaran Tematik}

Kegiatan Implementasi dilakukan pada tanggal 30 September 2020. Ditengah situasi pandemi yang memberikan keterbatasn untuk bertatap muka dengan ijin kepada Kepala Sekolah kegiatan Implementasi Asesmen Autentik dalam dilakukan secara luring dengan jumlah siswa setengah dari jumlah keseluruhan.

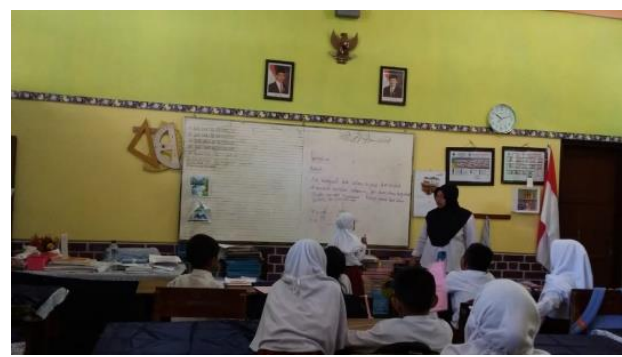

Gambar 5. Guru memberikan pengarahan kepada siswa

Pada kegiatan implementasi dilaksanakan sesuai dengan RPP yang sudah disusun oleh guru. Di awal kegiatan guru memberikan salam kemudian apresepsi dan menyampaikan tujuan pembelajara. Pada kegiatan inti siswa diminta untuk membaca LKPD dan kemudian menyelesaikan setiap tahapan sesuai dengan arahan guru. Terdapat 3 aspek penilaian yang natinya akan dilakukan oleh guru yaitu sikap, pengetahuan dan keterampilan. Pada penilaian sikap dilakukan dengan cara mengamati tingkah laku siswa ketika proses pembelajaran berlangsung, pada kegiatan keterampilan dilakukan dengan mengamati, contohnya ketika siswa diminta untuk menari maka penilaian yang dilakukan yaitu tentang ketepatan lagu, ketepatan gerakan. Dan yang terakhir tentang pengetahuan, pengetahuan dilakukan dengan memberikan soal evaluasi pada akhir pertemuan.

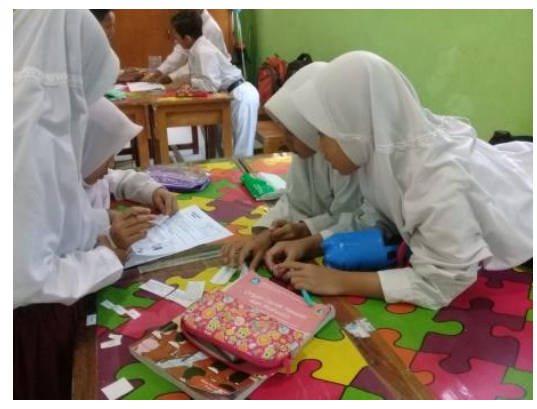

Gambar 6. Siswa menyelesaikan tugas yang diberikan oleh guru

Pada saat implementasi ditemukan beberapa kendala ketika menggunakan instrumen asesmen autentik. Kendala yang pertama adalah pada penilaian sikap, guru memasukkan jenis sikap yang 
bervariasi dan tidak muncul pada saat kegiatan pembelajaran sehingga pada kolom penilaian terdapat nilai sikap yang kosong. Kurang spesifiknya waktu pada kegiatan penilaian sehingga membuat bingung guru ketika pengambilan nilai. Kendala yang ditemukan pada siswa adalah kurang jelasnya kata perintah pada LKPD sehingga membuat bingung siswa ketika akan memulai mengerjakan.

\section{Evaluasi dan Refleksi}

Kegiatan evaluasi dengan memberikan angket ketika kegiatan workshop selesai. Kegaiatan pemberian angket untuk melihat ketercapaian dan kebermanfaatan kegiatan workshop penyusunan intrumen asesmen autentik. Dari hasil angket diperoleh bahwa guru mendapatkan pengetahuan baru tentang cara menyusun intrumen asesmen autentik yang mudah, praktis dan tepat sasaran. Selama ini yang digunakan guru untuk melalukan penilaian adalah dengan menggunakan pedoman buku guru dimana didalam buku guru kurang sesuai dengan karakteristik siswa di kelas. Dengan adanya workshop pendampingan penyusunan asesmen autentik guru dapat menyusun instrumen yang sesuai dengan kemampuan siswa.

\section{SIMPULAN}

Berdasarkan hasil pengabdian yang telah dilakukan, dapat disimpulkan bahwa kegiatan Pendampingan Penyusunan Asesmen Autentik Pada Pembelajaran Tematik di SDN Girimoyo 02 Kec. Karangploso Kab. Malang dilakukan melalui 4 tahapan. Yang pertama adalah kegiatan Workshop Penyusunan Asesmen Autentik, dalam kegiatan workshop terdapat 2 materi yang disampaikan yaitu pengertian,jenis-jenis dan langkah penyusunan asesmen autentik. Tahapan kedua adalah pendampingan penyusunan Asesmen autentik, pada tahap pendampingan dilakukan dengan daring (whatapps group) dan satu kali luring dengan tatap muka antara guru dan tim pengabdi. Tahapan ketiga yaitu implementasi asesmen autentik, tahapan implementasi dilakukan dengan jumlah siswa setengah dari jumlah keseluruhan dikarenakan pada situasi pandemi. Tahapan keempat dan terakhir adalah evalusi dan reflesi terkait penyusunan asesmen autentik. Kendala yang dialami ketika kegiatan pendampingan adalah waktu pendampingan yang terbilang singkat karena kegiatan penyusunan asesmen ini ditengah tengah kegiatan guru untuk mempersiapkan materi dan video untuk pembelajaran daring dan agenda sekolah lainnya.

\section{SARAN}

Penyusunan Asesmen Autentik pada pembelajaran tematik dapat dikembangkan ke yang lebih luas lagi dalam Tema. Dalam kegiatan pembelajaran tidak didominasi dengan memberikan kalimat soal akan tetapi bisa divariasi kedalam bentuk permainan. Dalam pemilihan jenis asesmen bisa divariasi pada pertemuan berikutnya, sehingga anak mengenal berbagai kegiatan. Agar penerapan asesmen autentik dapat berjalan secara maksimal perlu memperhatikan KD dan indikator pembelajaran.

\section{UCAPAN TERIMA KASIH}

Ucapan terimakasi kami sampaikan kepada kepala sekolah SDN girimoyo 2 beserta bapak/ibu guru yang telah membantu kegiatan pendampingan asesmen tematik di tingkat sekolah dasar.

\section{DAFTAR PUSTAKA}

Harsiati, Titik.2011. Penilaian dan Pembelajaran. Malang. Um Press

Kunandar. 2013. Penilaian Autentik: penilaian hasil belajar peserta didik berdasarkan kurikulum 2013. Jakarta. Rajawali Pers

O’Malley, J.M 7 Pierce, L. V. 1996. Authentic Asesment for English Language Learners

Protical Approach for Teacher. USA: Addison-Wesley Publishing.

Peraturan Menteri Pendidikan dan Kebudayaan (Permendikbud) Republik Indonesia Nomor

66 Tahun 2013, Standar Penilaian Pendidikan, (Lampiran)Bab II tentang Standar

Penilaian Pendidikan.

Zacharis, N.T. 2010. Innovative Assessment for Learning Enhancement: Issues and Practices. Contemporary Issues in Education Research. (Online), 3 (1):61 70(http://files.eric.ed.gov/fulltext/EJ1072576.pdf, diakses 9 Juli 2020) 